\title{
Minerals Identification and Analysis of Granite Rocks in South Aceh District Using X-Ray Diffraction (XRD)
}

\author{
Bakruddin Bin Dulah Iman ${ }^{\mathrm{a},}$, Arnold Rikardo Sihombing ${ }^{\mathrm{b}}$ \\ ${ }^{a}$ Departement of Industrial Engineering, Polytehcnic of Aceh Selatan, Tapaktuan, Aceh Selatan, 23711, Indonesia \\ ${ }^{b}$ Departement of Industrial Engineering, Polytehcnic of Aceh Selatan, Tapaktuan, Aceh Selatan, 23711, Indonesia \\ bakry.klt@gmail.com*
}

\begin{tabular}{|c|c|}
\hline ARTICLE INFO (8 pt) & ABSTRACT (10PT) \\
\hline $\begin{array}{l}\text { Keywords: } \\
\text { South Aceh } \\
\text { Non metal } \\
\text { Granite rocks } \\
\text { X-Ray Diffraction }\end{array}$ & $\begin{array}{l}\text { The potential of non-metallic natural resources in South Aceh } \\
\text { Regency is very abundant, one of which is granite rock. Granite rock } \\
\text { is igneous rock that can be used for a variety of household and } \\
\text { industrial products. This rock has certain characteristics based on its } \\
\text { constituent mineral structure. South Aceh granite rocks are scattered } \\
\text { in two different locations namely Samadua District and Sawang } \\
\text { District. This research was conducted to determine the constituent } \\
\text { mineral phase using the X-Ray Diffraction method. The results of } \\
\text { testing and analysis showed that granite rock samples taken from } \\
\text { Lhok pawoh village contained Quartz }\left(\mathrm{SiO}_{2}\right) \text { as the dominant phase, } \\
\text { while the minor phase was Aluminum oxide }\left(\mathrm{Al}_{2} \mathrm{O}_{3}\right) \text {. While the } \\
\text { granite rock samples taken from Ujung Karang Village have Quartz } \\
\text { (Sio2) as the dominant phase, while the minor phase is the dominant } \\
\text { mineral phase contained in the dominant phase, namely Aluminum } \\
\text { oxide (Al2O3). From the two samples above the high diffraction } \\
\text { pattern is owned by rock samples from Ujung Karang Village. }\end{array}$ \\
\hline
\end{tabular}

\section{Introduction}

South Aceh is a regency located on the southern west coast of Aceh Province. South Aceh has a variety of potential non-metallic mineral resources such as sirtu, basalt, limestone, quartzite, andesite, diorite, quartz sand, marble, clay, and granite. Granite rocks are intrusive igneous or volcanic rocks that contain silica compounds $\left(\mathrm{SioO}_{2}\right)$ or pure silica in two forms, quartz and cristobalite, these volcanic rocks are the most common rocks of the earth's crust formed from the slow cooling of magma[1]. The potential of granite rocks in Aceh Selatan based on data obtained is spread in two different locations namely Sawang District 225,000,000 tons, and Samadua District $130,000,000$ tons, the potential of these rocks has a large enough prospect to be utilized and developed for a variety of home products household and industrial[2][3]. Geologically rocks are formed from several types of minerals as compilers, and have certain crystal properties[4]. However, the granite rock in the two places mentioned above is not known for certain composition or mineral composition, for this it is necessary to conduct a fundamental study.

\section{Related Studies}

Grantite rocks are one of the rocks that have high economic value, so the researchers conducted a study of these rocks. The following is a study related to granite rocks conducted by previous researchers, namely the identification of minerals in granite rocks in Merangin Geopark using XRay Diffraction, the identification results obtained by three mineral phases namely quartz, anorthoclase, and Muskovit[5]. Later research related to the dartmoor granite mineral, structural form and petrological observations, these results say that the rough granite rocks tend to be biotite mineral content[6]. Then in other studies characterizing minerals using X-ray Diffraction on granite 
rocks, the results of the analysis show that there are mineral phases of Quartz, Orthoclast, Albite, Magnetite, Thorite, Ilminite, Hornblende, Kaolinite, Muscovite, and Sodalite [7][3].

\section{Method}

\section{A. Rock Sampling}

In this study, granite rock samples were taken from two different locations, in Sawang District, South Aceh Regency, namely Lhok Pawoh Village and Ujung Karang Village. The rock sample is then carried out the cleaning process and then smoothing until it becomes in the form of powder size. The research flow diagram can be seen as shown in Figure 1 below.

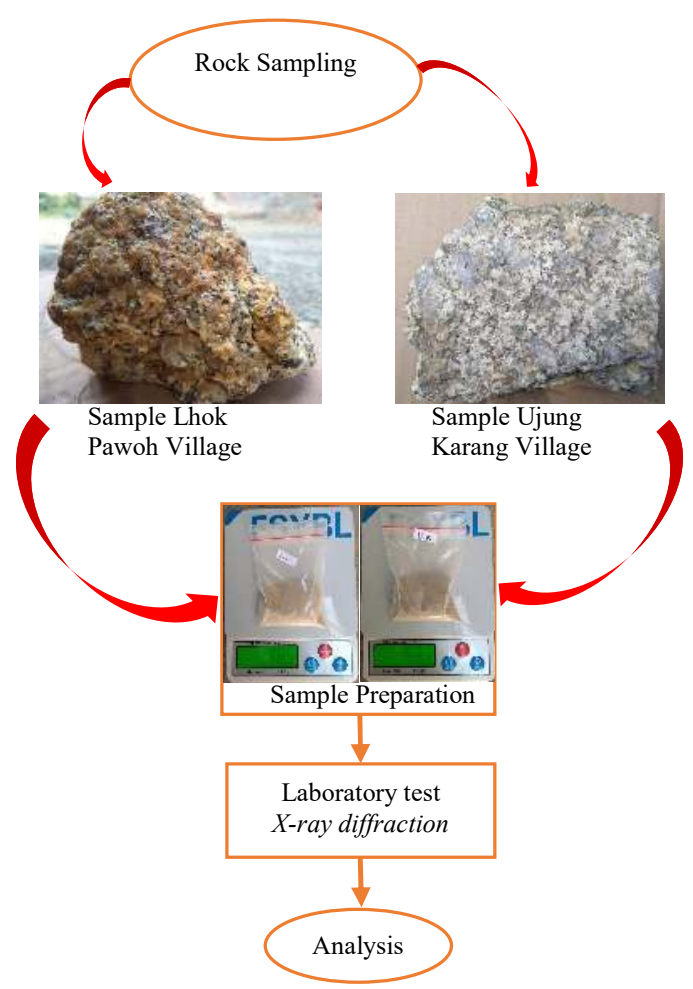

Figure 1. Research flow chart

\section{B. Sample Testing}

Granite rock samples In this study sample testing in the laboratory is to do the rock sample testing process to obtain the mineral phase composition using an X-ray Diffractometer (XRD) machine with Shimadzu X-ray diffraction techniques, Co-K $\alpha$ radiation $(\lambda=1.54060 \AA)$ on angle $2 \Theta$.

\section{Results and Discussion}

XRD test results on granite rock samples from two different locations have different diffraction patterns. Data obtained from X-ray testing are diffraction angle (20), distance between fields (d), and diffraction intensity value (I). The X-ray diffraction technique used is Shimadzu, Co-K radiation Co$\mathrm{K} \alpha(\lambda=1.54060 \AA)$ at an angle of $2 \Theta$.

\section{A. XRD granite rocks Lhok Pawoh village}

Granite rock samples obtained from Lhok Pawoh Village based on the results of X-ray diffraction tests contained 31 identified mineral phases, where there were 3 highest peaks called the 
major phases, while the rest were minor phases as shown in Table 1, while the diffraction patterns The resulting $X$ is shown in Figure 2, while the phase is Quartz (Sio2) as the dominant phase, while the minor phase is Aluminum oxide (Al2O3).

Table 1. X-Ray Diffraction data sample of Lhok Pawoh Village

\begin{tabular}{ccccc}
\hline No & $2 \Theta\left({ }^{\circ}\right)$ & $\mathrm{d}\left(A^{\circ}\right)$ & Intensity & FWHM \\
\hline 1 & 26.8908 & 3.31559 & 100 & 0.0984 \\
2 & 27.6816 & 3.22264 & 45 & 0.1574 \\
3 & 36.8139 & 2.43948 & 34 & 0.0480 \\
\hline
\end{tabular}

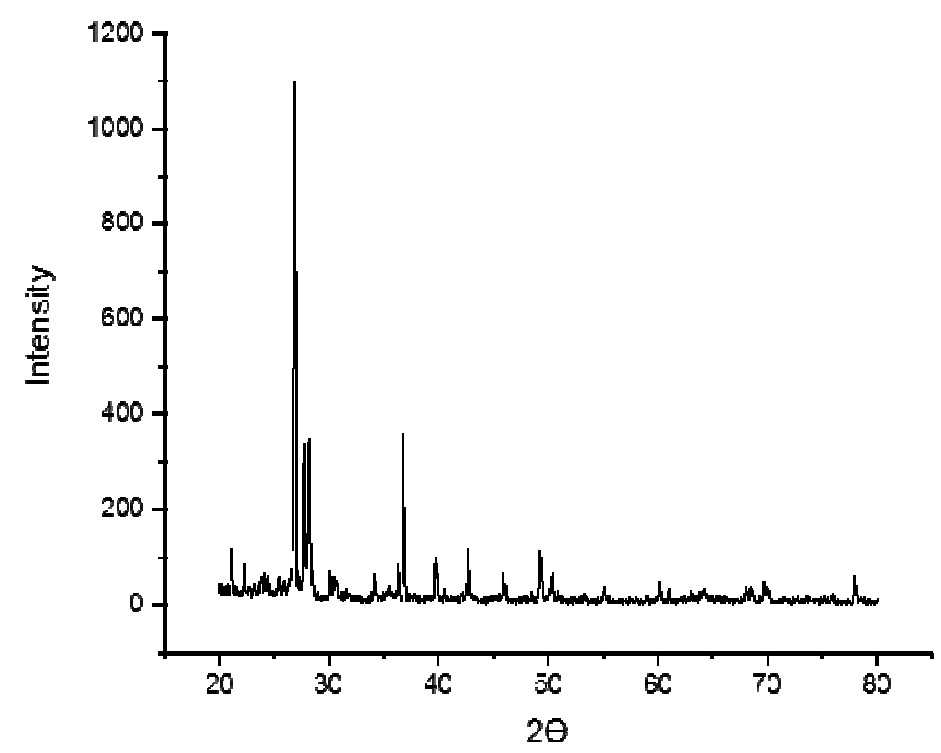

Gambar 2. X-Ray Diffraction Pattern of rock samples in Lhok Pawoh Villege

\section{B. XRD granite rocks Ujung Karang village}

Granite rock samples obtained from Ujung Karang based on X-ray diffraction test results found 40 mineral phases detected, where there were 3 highest peaks called the major phase, while the rest were minor phases as shown in Table 2, while the X-ray diffraction pattern produced as shown in Figure 3, while the phase is almost the same as the rock sample from Lhok Pawoh Village, Quartz $\left(\mathrm{SiO}_{2}\right)$ as the dominant phase, while the minor phase is Aluminum oxide $\left(\mathrm{Al}_{2} \mathrm{O}_{3}\right)$.

Table 1. X-Ray Diffraction data sample of Ujung Karang Village

\begin{tabular}{ccccc}
\hline No & $2 \Theta\left({ }^{\circ}\right)$ & $\mathrm{d}\left(A^{\circ}\right)$ & Intensity & FWHM \\
\hline 1 & 27.7217 & 3.21307 & 100 & 0.1378 \\
2 & 27.1596 & 3.16902 & 97 & 0.1181 \\
3 & 26.8039 & 3.32614 & 79 & 0.1378 \\
\hline
\end{tabular}




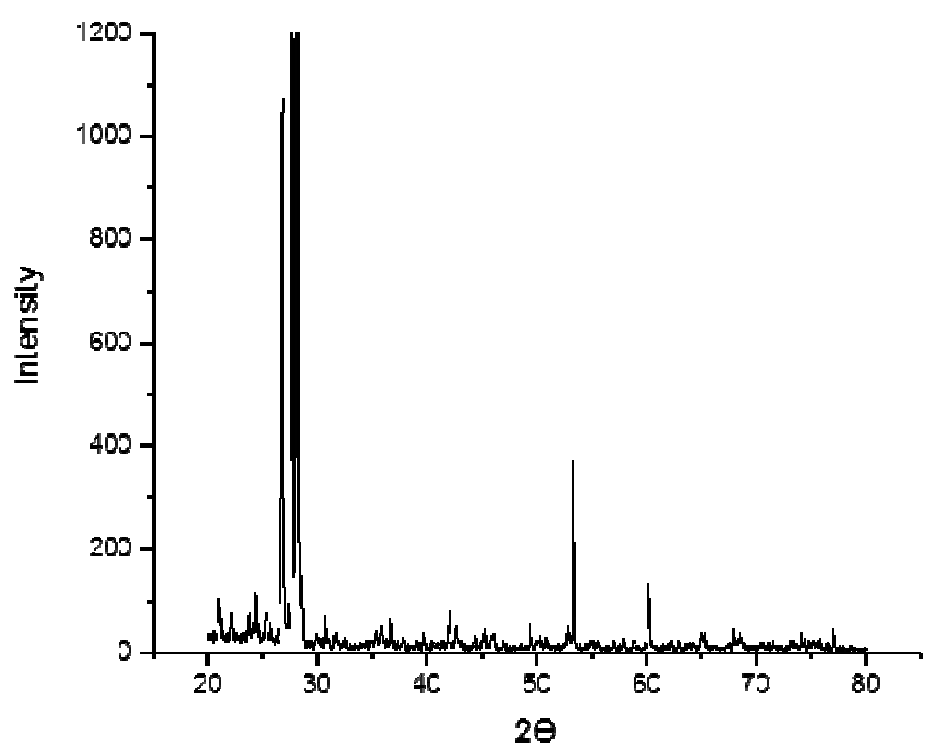

Fifure 3. X-Ray Diffraction Pattern of rock samples in Ujung Karang Villege

\section{Conclusion}

Based on the results of research that has been done, the mineral phases that emerge from granite rock samples taken from two different locations namely Lhok Pawoh Village and Ujung Karang Village have similarities in mineral phases as the constituents are Quartz minerals $\left(\mathrm{SiO}_{2}\right)$ dominant phase, and Aluminum oxide $\left(\mathrm{Al}_{2} \mathrm{O}_{3}\right)$ as a minor phase. However, if observed visually this rock has a very significant difference, namely in the rock sample Lhok Pawoh Village has a yellow and white color, while the rock sample in Ujung Karang Village has a gray and white color. For this reason, the researcher recommends further testing using XRF and Migration Observation using SEM.

\section{Acknowledgment}

The author would like to thank the Direktorat Jenderal Penelitian dan Pengabdian Masyarakat for funding this research through the Penelitian Dosen Pemula Program in 2019. And the authors also express their thanks to the Laboratory of Mineral dan Material Maju (Sentral) Fakultas dan Ilmu Pengetahuan alam (FMIPA) Universitas Malang for opportunity to do sample testing.

\section{References}

[1] G. Bayrak and S. Yilmaz, "Granite based glass-Ceramic materials," Acta Phys. Pol. A, vol. 125, no. 2, pp. 623-625, 2014.

[2] B. S. Zulfikar, Iwan Aswan H., Corry Karangan, "Inventarisasi dan Penyelidikan Mineral Non Logam Kabupaten Aceh Selatan, Provinsi Nanggroe Aceh Darussalam," In Inventarisasi dan Penyelidikan Mineral Non Logam Kabupaten Aceh Selatan, Provinsi Nangroe Aceh Darussalam, 2006.

[3] S. Audah, "Utilization of GPS data in the effort of Mineral Identification in Granite Rocks Using X-Ray Diffraction in Samadua District, South Aceh,” vol. 4, no. 1, pp. 1-6, 2019.

[4] L. Lindawati and M. Mursal, "XRD Analysis of Mineral Composition in Marble from Gunung Kerambil, South Aceh,” J. Inotera, vol. 3, no. 2, pp. 65-69, 2018.

[5] S. Oktamuliani, "Identifikasi Mineral Pada Batuan Granit di Geopark Merangin Provinsi Jambi Menggunakan X-Ray Diffraction ( XRD ) Dan,” vol. 1, no. November 2015, pp. 12- 
17, 2016.

[6] H. L. Allsopp, "Rb-Sr Age Measurements on Total Rock and Separated-," vol. 55, 1961.

[7] Bajili, A., Hamdi \& Dwiridal, L., 2014. Karakterisasi Mineral pada Batu Granit di Sekitar Gunung Marapi Daerah Sumatera Barat Menggunakan X-Ray Diffraction (XRD). PILLAR OF PHYSICS, Vol. 1., pp. 01-08. 